\title{
An Analysis of Pre-service Teachers' Attitudes towards Environmental Issues in Terms of Various Variables
}

\author{
Rabia Sarıkaya ${ }^{1}$, Esra Saraç, ${ }^{2, *}$ \\ ${ }^{1}$ Faculty of Education, Gazi University, Turkey \\ ${ }^{2}$ Faculty of Education, Kilis 7 Aralık University, Turkey
}

Copyright $\odot 2018$ by authors, all rights reserved. Authors agree that this article remains permanently open access under the terms of the Creative Commons Attribution License 4.0 International License

\begin{abstract}
In this study, the attitudes of the pre-service teachers towards environmental issues are analysed by such variables as gender, the department of education, year, department, taking or not taking environmental education course, participating in any environmental activity, being a member of any environmental organization, and the longest duration of residence, respectively. This study is designed in the descriptive survey model, and was conducted in the 2016-2017 academic year. The research sample consists of 316 pre-service teachers who are studying in elementary education and science education programs determined by the use of convenient sampling method. The data were collected with a 20-item "Attitude Scale for Environmental Issues" developed by Saraç and Kan (2015). According to results of this study, it was found that pre-service teachers have high mean scores $(\bar{X}=76.50)$ about the attitudes of environmental issues. The attitude scores of the pre-service teachers were not significantly different according to gender, department, and the longest duration of residence, whereas there were significant differences according to year, whether or not they took any courses on environment, whether or not they participated in any environmental-related activity, and whether or not they had a membership in any environmental group. Based on the results of the study, it can be proposed to increase the number of applied studies on constructing environmental training courses based on active learning and developing attitudes towards learning and teaching about environmental issues.
\end{abstract}

Keywords Environmental Issues, Attitudes, Pre-service Elementary Teachers, Pre-service Science Teachers

\section{Introduction}

Since ecology is a multidisciplinary concept, different branches of science have different approaches towards environmental science in the literature [31, 35, 13]. On examining the resources related to ecology; the following sub-titles have been observed, including elements that constitute the ecosystem, ecosystem types, functions of ecosystem and energy flow, population and communal ecology and environmental problems (air/water/soil pollution, erosion, genetically modified organisms, global climate change, ozone destruction, noise and light pollution, biodiversity degradation, electromagnetic and radioactive pollution, wastes). The issue of environmental problems stands out since they are increasing day by day in the world we live in. At this point, it is of great importance to educate individuals who are aware of environmental problems and who are able to come up with solutions to these problems. An emphasized fact is that while taking decisions about the environment, individuals should display eco-friendly behavior which is compatible with the "Eco-centric" approach, which aims to protect all living and non-living beings, considering not only the human benefit but all ecosystems, rather than the "Anthropocentric" approach that embraces the philosophy that everything exists in nature in order to benefit people. According to Casas and Burgess (2012), anthropocentrism and ecocentrism are philosophical elaborations of the more commonly used terms conservation and preservation. Anthropocentrism is a perspective that human beings are the most significant species on the planet, and nature is "valuable only insofar it is valuable to human beings". And also Donnelly and Bishop (2007) define an anthropocentric action as "one in which the reason to act is the provision of a benefit to human beings". In addition to this definition of anthropocentrism does not explicitly make a reference to future generations, it seems similar to the definition of conservation, which is the management and protection of nature for the benefit of present and next generations of humans [10]. On the other hand, ecocentrism is a perspective that human beings are not the center of the planet's reason to be, and "the environment is intrinsically valuable" [7]. Some definitions of ecocentrism also add that humans are solely equal members of the wide 
community of nature. According to Donnelly and Bishop (2007), ecocentric action is "one in which the reason to act is the provision of a benefit to the environment" which sounds very much like preservation. Environmental education is one of the most important factors in the upbringing of such individuals who have high environmental awareness and positive environmental behavior. According to Aldrich and Benjamin (1997), environmental education contributes to understanding and solving environmental problems.

Polat (1999) and Özoğlu (1993) emphasize the importance of environmental education as "the development of environmental awareness in individuals, the acquisition of environmentally sensitive, positive and permanent behavioral changes, the protection of natural, historical, cultural and socio-aesthetic values, ensuring active participation and undertaking the task of solving environmental problems, or recognizing and distinguishing the values, attitudes, concepts related to the bio-physical and social environment of individuals". Environmental education lies at the heart of the community's adequate knowledge and awareness about the environment, the creation of positive attitudes and behavioral changes, the preservation of the natural environment and the repair of the damaged environment. Environmental education is an interdisciplinary approach aimed at educating individuals who are conscious in environmental issues, who have the knowledge, skills, attitude, motivation, individual and social responsibility, and who can contribute to the solution of environmental problems [29]. In this context, one of the most important and ultimate goals of environmental education is to raise environmental literacy among individuals [36]. Environmental literacy primarily involves knowledge, attitudes and active participation for a sustainable environment [Orr, 1992, as cited in 9]. Researches states that for the changing and addressing persons' environmental behaviors, and in turning society towards sustainability environmental knowledge could be play a significant role [45]. Schultz et al. (2004) describe environmental attitudes as individuals' relation about the environmental issues. Sets of environmental attitudes form a person's character towards the protection or utilization of the environment [20]. The person's character towards the environment may impact subsequent environmental behavior [28]. Despite the fact that environmental knowledge is regarded important for exhibiting environmental behavior, it is the environmental attitudes and individual's sense of responsibility towards the environment that really shape environmentally friendly behavior [19]. For this reason, environmental attitudes play an important role in determining environmental behaviors [33].

The success of the students at each stage and in the field of education is related to the quality of the teachers [21]. Teachers play an important role in teaching environmental issues. A teacher's experience, opinions and attitudes about the subject to be taught directly influence the attitudes and success of his/her students [8]. According to Cheng and So (2015), teachers' environmental literacy and beliefs, and how environmental education is conducted are also important variables affecting how students learn about environmental issues. Teachers have a crucial role in educating students as green citizens who are knowledgeable about environmental issues, environmentally-conscious and responsible. In the case that teachers are not sufficiently prepared to teach about environmental issues, hopes for children to solve environmental problems will diminish accordingly. However, teachers who are eager and ready to teach about environmental issues can have permanent impact on their students [Darling-Hammond, Wei and Johnson, 2009, as cited in 4]. In order for teachers to be able to provide an effective environmental education to their students, they must first have sound knowledge on environmental issues. Additionally, they must also be competent in teaching environmental issues and take an attitude that demonstrates the importance of teaching them [4]. Vlaardingerbroek and Taylor (2007) emphasized that the "teacher" is one of the most important factors in determining the quality of environmental education in schools, and that the quality of environmental education depends on teachers' awareness and consciousness about environmental problems, environmental protection and environmental education.

A number of scientific studies also support the idea that teachers have influence on students' knowledge about the environment, their environmental attitudes and environmental-friendly behaviors. It is not surprising that students are influenced by their teachers because environmental issues are taught by teachers in formal education. A teacher who wants to raise environmental awareness in his/her student should firstly motivate his/her students learn about environmental issues by drawing attention to them. Thus, students will become knowledgeable about the environment. Yet, being knowledgeable is not sufficient for environmental awareness. Students need to acquire positive attitudes towards the environment in the second step, and these positive attitudes should transform into behavior in the third step. The more the students become knowledgeable about environmental issues, the more they will be able to analyze environmental relationships, recognize the importance of ecological balance and realize that ecological equilibrium interventions will result in an environmental response. Thus, they will gain positive environmental attitudes and feel a sense of responsibility towards the environment. The next task for the teacher is to make their students think about the cost of every behavior in daily life and mobilize them about what they should do to protect the ecological services that are provided free to human beings. In this way, students will gain environmental knowledge, positive environmental attitude and environmental-friendly behaviors. Environmental awareness will not occur if one of these three steps is 
missing.

Scientific studies on pre-service teachers who form the attitudes towards the environment and serve as bridges for acquiring knowledge are frequently found in the literature. However, these studies have measured the environmental knowledge of the pre-service teachers and their attitudes towards environment/environmental problems $[26,16,46$, $14,25]$ or their environmental literacy involving such factors $[9,47,33,30]$. However, in order for the individual to develop attitudes and behaviors towards the environment or environmental problems, first, it is necessary to establish a positive attitude towards understanding and learning them, and teaching about them. Unlike the other studies in the literature, the purpose of this study is to reveal the attitudes of the pre-service teachers to the learning and teaching of the environmental issues and examine them in terms of different variables. It is thought that the results obtained from this research will also shed light on other possible studies to be carried out in the future.

\section{Method}

\subsection{Research Design}

This study is a quantitative descriptive study designed in a survey model, and is suitable for quantitative approach. Surveys are studies in which the views of the participants on a topic or their characteristics such as interest, skill, attitude or ability are identified. Survey researchers are interested in how opinions and characteristics are scattered according to the individuals in the sample rather than where they originate from [18].

\subsection{Participants}

Table 1. Demographic Features of Pre-service Teachers

\begin{tabular}{|c|c|c|c|}
\hline \multicolumn{2}{|c|}{ Demographic Features } & $\mathrm{f}$ & $\%$ \\
\hline \multirow{2}{*}{ Gender } & Female & 253 & 80 \\
\cline { 2 - 4 } & Male & 63 & 20 \\
\hline \multirow{3}{*}{$\begin{array}{c}\text { Undergraduate Program } \\
\text { Grade }\end{array}$} & $\begin{array}{c}\text { Elementary } \\
\text { Education }\end{array}$ & 191 & 60 \\
\cline { 2 - 4 } & $\begin{array}{c}\text { Science } \\
\text { Education }\end{array}$ & 125 & 40 \\
\hline \multirow{2}{*}{$\begin{array}{c}\text { Place with the Longest Duration of } \\
\text { Residence }\end{array}$} & Freshmen & 76 & 24 \\
\cline { 2 - 4 } & Sophomores & 91 & 28 \\
\cline { 2 - 4 } & Juniors & 84 & 27 \\
\cline { 2 - 4 } & Seniors & 65 & 21 \\
\hline Membership in an Environmental & Urban & 90 & 29 \\
\cline { 2 - 4 } Organization & Yes & 74 & 24 \\
\cline { 2 - 4 } & No & 242 & 76 \\
\hline Participation in Environmental & Yes & 145 & 46 \\
\cline { 2 - 4 } Activities & No & 171 & 54 \\
\hline \multirow{2}{*}{\begin{tabular}{c} 
Taking Environmental Course \\
\cline { 2 - 4 }
\end{tabular}} & Yes & 221 & 70 \\
\cline { 2 - 4 } & No & 95 & 30 \\
\hline
\end{tabular}

Convenience sampling method is used in this study. In the cases where it is difficult or impossible to reach the whole of the sample universe, researchers can work with appropriate sample groups to represent the study universe [18]. In this study, the data were analyzed with a sample representing the community to be characterized and the subject to be investigated was tried to be understood through the selected sample. The sample of the study is composed of 316 pre-service teachers who are studying in undergraduate programs of science education and elementary education of a state university in Southeastern Anatolia region in Turkey in the academic year of 2016-2017. Distribution of pre-service teachers according to their demographic characteristics is given in Table 1.

\subsection{Research Instruments}

In this study, data were collected by using "Attitude Scale for Environmental Issues" developed by Saraç ve Kan (2015). The 20-item scale is of the five-point Likert type. The scale is a three-factor structure consisting of "Positive Feelings Towards Learning About and Teaching Environmental Issues", "Negative Feelings Towards Learning About and Teaching Environmental Issues", and "Activities Towards Environmental Issues". The reliability of the scale developed in 2015 has been reviewed for this research with the Pre-service teachers in the study group. The Cronbach Alpha internal consistency coefficient was calculated as .875 .

\subsection{Data Analysis}

In the analysis of the data, besides frequency, percentage and arithmetic mean, "t-test of independent groups" was used in the comparison of two groups whereas "one-way variance analysis (ANOVA)" was used in the comparison of more than two groups. The Tukey HSD test (PostHoc) was used to determine the groups in which the statistical difference emerged in binary comparisons following the analysis of variance. The significance level in the statistical analysis of the scale was accepted as .05. Effect size values were also examined to determine whether the differences were practically significant. Cohen's (1988) suggestions were used in interpreting the effect sizes (n2).

\section{Findings and Interpretation}

The purpose of this study is to reveal the attitudes of the pre-service teachers towards environmental issues and to examine them in terms of different variables. Relevant results are presented below.

Percentage and frequency analysis of the scores of the pre-service teachers who form the sample of this study and their attitudes towards environmental issues are given in Table 2. 
Table 2. Percentage and frequency analysis of pre-service teachers' scores obtained from the attitude scale for environmental issues

\begin{tabular}{|c|c|c|c|c|c|c|c|c|c|c|}
\hline & \multicolumn{2}{|c|}{ I Strongly Agree } & \multicolumn{2}{|c|}{ I Agree } & \multicolumn{2}{|c|}{ Undecided } & \multicolumn{2}{|c|}{ I Disagree } & \multicolumn{2}{|c|}{ I Strongly Disagree } \\
\hline & f & $\%$ & f & $\%$ & f & $\%$ & f & $\%$ & f & $\%$ \\
\hline I am very much interested in topics related to the environment. & 93 & 29 & 177 & 56 & 33 & 10 & 9 & 3 & 4 & 2 \\
\hline I feel excited to talk about topics related to the environmental. & 45 & 14 & 162 & 51 & 85 & 27 & 21 & 7 & 3 & 1 \\
\hline I enjoy talking about environmental issues. & 61 & 19 & 162 & 51 & 74 & 23 & 14 & 5 & 5 & 2 \\
\hline I believe that it is hard to learn the concepts about the environment. & 15 & 5 & 40 & 13 & 58 & 18 & 132 & 42 & 71 & 22 \\
\hline I teach the topics about the environment only because they are on the curriculum. & 5 & 2 & 26 & 9 & 39 & 12 & 175 & 55 & 71 & 22 \\
\hline I feel comfortable when I teach topics about the environment. & 75 & 24 & 173 & 54 & 50 & 16 & 15 & 5 & 3 & 1 \\
\hline I research the things I'm curious about the environment through the Internet, books, magazines etc. & 82 & 26 & 165 & 52 & 43 & 13 & 22 & 7 & 4 & 2 \\
\hline I watch videos about the environmental issues. & 63 & 20 & 152 & 48 & 60 & 19 & 34 & 11 & 7 & 2 \\
\hline I feel bored when I teach about the environmental issues. & 2 & 1 & 15 & 5 & 44 & 14 & 166 & 52 & 89 & 28 \\
\hline I would like to subscribe to a magazine/magazines that are published about environmental issues. & 52 & 16 & 103 & 32 & 116 & 37 & 37 & 12 & 8 & 3 \\
\hline I believe that I will have difficulty in teaching topics about the environment in the future. & 5 & 2 & 28 & 9 & 47 & 15 & 149 & 47 & 87 & 27 \\
\hline I always want to buy books or magazines about the environment whenever I come across. & 37 & 12 & 118 & 37 & 113 & 36 & 39 & 12 & 9 & 3 \\
\hline I would not teach the topics about the environment if it were an option. & 3 & 1 & 16 & 5 & 26 & 8 & 146 & 46 & 125 & 40 \\
\hline I attend seminars or conferences on environmental issues. & 38 & 12 & 148 & 47 & 85 & 27 & 37 & 12 & 8 & 2 \\
\hline I would like to attend trainings in order to have a better understanding of environmental issues. & 82 & 26 & 158 & 50 & 57 & 18 & 18 & 5 & 1 & 1 \\
\hline I chat to/discuss with my friends, teachers or family about environmental issues. & 46 & 14 & 173 & 55 & 58 & 19 & 33 & 10 & 6 & 2 \\
\hline I have difficulty in learning environmental issues. & 6 & 2 & 13 & 4 & 36 & 12 & 160 & 50 & 101 & 32 \\
\hline I follow environmental issues through visual, written or social media. & 44 & 14 & 152 & 48 & 83 & 26 & 33 & 10 & 4 & 2 \\
\hline I feel uneasy about teaching topics about the environment. & 4 & 2 & 15 & 5 & 32 & 10 & 169 & 53 & 96 & 30 \\
\hline I would like to be a member of non-governmental organizations that work for environmental issues. & 70 & 22 & 123 & 39 & 83 & 26 & 32 & 10 & 8 & 3 \\
\hline
\end{tabular}


When the scores obtained by pre-service teachers from the attitude scale towards environmental issues were evaluated item by item, it was observed that the majority of the participants gave such responses as that "I am very much interested in environmental issues", "I enjoy talking about environmental issues", "I feel comfortable when I teach topics about the environment", "I would like to attend trainings in order to have a better understanding of environmental issues", which could be interpreted that the participants had positive attitudes to learning about and teaching topics about the environment. Additionally, even though the higher number of pre-service teachers who presented a positive attitudes towards such items with similar judgment as "I would like to subscribe to a magazine/magazines that are published about environmental issues", "I always want to buy books or magazines about the environment whenever I come across", "I would like to be a member of non-governmental organizations that work for environmental issues", "I attend seminars or conferences on environmental issues", "I follow environmental issues through visual, written or social media", it is seen that a considerable amount of pre-service teachers do not agree with such expressions or they remain undecided.

When the answers given to the items were examined in detail, it was determined that the attitudes of the pre-service teachers were low especially in situations requiring active participation. This result suggests that pre-service teachers do not internalize the topics related to the environment to such an extent which is enough to become a member of an environmental community, participate in seminars/conferences related to environmental issues, or follow such issues on their own volition through media. This may result from the theoretical teaching of environmental education courses, rather than applied.

It could be assumed that pre-service teachers have basic knowledge about the environmental issues and gain awareness about the issues related to the environment with the focus on the theoretical teaching of the lessons. For this reason, there are positive attitudes towards items such as interest in environmental issues and feeling comfortable while teaching environmental issues, whereas more negative or indecisive expressions may have come to the forefront towards items requiring active participation.

Table 3 presents the data on the general distribution of the scores obtained by pre-service teachers on the attitude scale for environmental issues.

Table 3. Overall distribution of the scores obtained by pre-service teachers on the attitude scale for environmental issues

\begin{tabular}{|c|c|c|c|c|}
\hline $\mathbf{N}$ & Minimum score & Maximum score & $\overline{\mathbf{X}}$ & Ss \\
\hline 316 & 20 & 100 & 76.50 & 9.82 \\
\hline
\end{tabular}

As seen in Table 3, the mean value of the attitude scores of pre-service teachers towards the environmental issues is 76.50. Based on this value, it can be said that the pre-service teachers' attitude scores towards environmental issues are high.

Independent groups t-test was conducted to analyze whether the attitude scores of the participants in this study have changed according to such variables as gender (Table 4), whether he/she has taken an environment lesson (Table 5 ), the type of undergraduate program (Table 6), the longest duration of residence (Table 7), environment related activities (Table 8), being a member of an environmental organization (Table 9), and the results are presented below.

Table 4. Independent groups' t-test results on the attitudes towards such variables as gender and environmental issues

\begin{tabular}{|c|c|c|c|c|c|c|}
\hline Groups & $\mathbf{N}$ & $\overline{\mathbf{X}}$ & Ss & Sd & $\mathbf{t}$ & $\mathbf{p}$ \\
\hline Female & 253 & 76.79 & 9.73 & 314 & .927 & .355 \\
\hline Male & 63 & 75.50 & 10.17 & & & \\
\hline
\end{tabular}

On examining Table 4, it can be said that the mean value of the attitude scores of the female pre-service teachers is higher than that of the male pre-service teachers. However, the result of the t-test, which has been conducted to observe whether this difference is statistically significant, reveals that the difference is not statistically significant. The lack of a significant difference among the attitude scores of the pre-service teachers towards the environmental issues according to gender can be interpreted that the gender variable does not affect the attitudes of the pre-service teachers about the environmental issues.

Table 5. Independent t-test results on the variable about whether the pre-service teacher has taken an environment course and attitudes towards environmental issues

\begin{tabular}{|c|c|c|c|c|c|c|}
\hline Groups & $\mathbf{N}$ & $\overline{\mathbf{X}}$ & Ss & Sd & $\mathbf{t}$ & $\mathbf{p}$ \\
\hline $\begin{array}{c}\text { Taking an } \\
\text { environmental course }\end{array}$ & 221 & 77.64 & 9.52 & 314 & 3.173 & .002 \\
\hline $\begin{array}{c}\text { No environmental } \\
\text { course }\end{array}$ & 95 & 73.87 & 10.04 & & & \\
\hline
\end{tabular}

On examining Table 5, it is seen that the arithmetic mean of the attitude scores of the pre-service teachers who took environmental courses are higher than that of the pre-service teachers who have not taken environmental courses. A statistical significance was found as a result of the t-test conducted to test whether this difference was significant.

Environmental course includes basic concepts about the environment, environmental problems, biodiversity and environmental education etc. This course is given during a semester. Pre-service elementary teachers take this course in the second grade. Pre-service science teachers take this course in the third grade. The fact that the attitude scores were found in favor of pre-service teachers who took environmental courses show that environmental courses may affect the attitudes of pre-service teachers towards the environment. However, this variable was found to have a small value $(\mathrm{n} 2=0.05)$ when the magnitude of effect size of the variable was examined (Cohen, 1988). In this case, the environmental courses variable alone appears to have a minor impact on influencing participants' attitudes towards 
environmental issues.

Table 6. Independent t-test results related to the undergraduate program variable and attitudes towards environmental issues

\begin{tabular}{|c|c|c|c|c|c|c|}
\hline Groups & $\mathbf{N}$ & $\overline{\mathbf{X}}$ & Ss & sd & $\mathbf{t}$ & $\mathbf{p}$ \\
\hline $\begin{array}{c}\text { Elementary } \\
\text { Education }\end{array}$ & 191 & 75.97 & 9.69 & 314 & -1.19 & .231 \\
\hline Science Education & 125 & 77.32 & 9.98 & & & \\
\hline
\end{tabular}

In Turkey, only elementary education and science education programs necessarily include the environmental courses. On examining Table 6, it is seen that the mean of the attitude scores of the pre-service science teachers is higher than the mean of the attitude scores of the pre-service elementary teachers. However, the result of the t-test, which has been conducted to observe whether this difference is statistically significant, reveals that the difference is not statistically significant. Hence, it can be said that the departments they have studied do not create a statistical significance on the attitudes of pre-service teachers towards the environmental issues, which may result from the fact that the contents of the environmental courses in both departments are similar.

Table 7. Independent t-test results related to the longest duration of residence variable and attitudes towards environmental issues

\begin{tabular}{|c|c|c|c|c|c|c|}
\hline Groups & N & $\overline{\mathbf{X}}$ & ss & Sd & t & p \\
\hline Rural & 90 & 76.01 & 9.24 & 314 & -.569 & .570 \\
\hline Urban & 226 & 76.70 & 10.05 & & & \\
\hline
\end{tabular}

Table 7 shows that there is a slight difference between the mean values of the attitude scores of those living in the rural area for the longest and those living in the urban area for the longest, which is not statistically significant $(\mathrm{p}>0,05)$. This result can be interpreted that the close environment where pre-service teachers spend most of their lives do not influence their attitudes towards environmental issues $(\mathrm{p}>0,05)$.

Table 8. Independent t-test results related to the activity variable and attitudes towards activity variables

\begin{tabular}{|c|c|c|c|c|c|c|}
\hline Groups & $\mathbf{N}$ & $\overline{\mathbf{X}}$ & $\mathbf{S s}$ & $\mathbf{s d}$ & $\mathbf{t}$ & $\mathbf{p}$ \\
\hline $\begin{array}{c}\text { Having participation in an } \\
\text { environmental activity }\end{array}$ & 145 & 79.93 & 8.86 & 314 & 6.035 & .000 \\
\hline $\begin{array}{c}\text { Not having participated in an } \\
\text { environmental activity }\end{array}$ & 171 & 73.57 & 9.68 & & & \\
\hline
\end{tabular}

Environmental activities include conferences, seminars, nature trips and camps, and environmental movements related to environmental issues. These activities aren't mandatory to participate for pre-service teachers. Participants voluntarily engage in environmental events. On examining Table 8 , it is seen that the arithmetic mean value of the attitude scores of the pre-service teachers who participate in any activity related to the environment is higher than that of the pre-service teachers who do not participate in any activity related to the environment, and the difference between the mean values is statistically significant $(p<0,05)$. When the effect size value of environmental activity variable is examined, it is seen that it has a moderate value $(\mathrm{n} 2=0.32)$ (Cohen, 1988). Accordingly, it can be assumed that participating in activities related to the environment positively affects the attitudes of the pre-service teachers.

Table 9. Independent t-test results related to the variable about a membership to an environmental organization and attitudes towards environmental issues

\begin{tabular}{|c|c|c|c|c|c|c|}
\hline Groups & $\mathbf{N}$ & $\overline{\mathbf{X}}$ & $\mathbf{s s}$ & $\mathbf{S d}$ & $\mathbf{t}$ & $\mathbf{p}$ \\
\hline $\begin{array}{c}\text { Membership in an } \\
\text { Environmental } \\
\text { Organization }\end{array}$ & 74 & 81.13 & 8.89 & 314 & 4.789 & .000 \\
\hline $\begin{array}{c}\text { Non-membership in an } \\
\text { Environmental } \\
\text { Organization }\end{array}$ & 242 & 75.09 & 9.67 & & & \\
\hline
\end{tabular}

Environmental organizations include Greenpeace, WWF, TEMA and other non-governmental organizations which is working on environmental issues. According to the results of the analysis in Table 9, it is seen that the arithmetic mean value of the attitude scores of the pre-service teachers who are members of any environmental organization are higher than that of the pre-service teachers who are not members of an environmental organization, and the difference between the mean values is statistically significant ( $p$ $<0,05$ ). On examining the effect size value of the variable of non-membership in any environmental organization, it was found to have a moderate value $(\eta 2=0.26)$ (Cohen, 1988). The fact that the attitude scores are significant for the pre-service teachers who are members in environmental organizations can be interpreted that the activities carried out in the environmental organizations may positively affect the attitudes of the pre-service teachers towards the environment.

Table 10 shows the distribution of the scores obtained from the attitude scales for environmental issues according to the year of education of the pre-service teachers in this study. One-way analysis of variance (ANOVA) was conducted to analyze whether the sample teachers' attitudes towards environmental issues vary according to the year of education, and the results are presented in Table 11.

Table 10. The distribution of the scores that the pre-service teachers get from the attitude scale for environmental issues according to the grade variable

\begin{tabular}{|c|c|c|c|}
\hline Grade & $\mathbf{N}$ & $\overline{\mathbf{X}}$ & Ss \\
\hline Freshmen & 76 & 73.39 & 10.51 \\
\hline Sophomores & 91 & 77,35 & 9.03 \\
\hline Juniors & 84 & 75,92 & 9.84 \\
\hline Seniors & 65 & 79,72 & 9.01 \\
\hline Total & 316 & 76,50 & 9.82 \\
\hline
\end{tabular}

On examining Table 10, it is seen that the pre-service teachers have the highest mean value of the attitude scores for the environmental issues in the $4^{\text {th }}$ year (seniors) and the lowest in the $1^{\text {st }}$ year (freshmen). This can be interpreted as the development of the attitudes of the pre-service teachers towards the environmental issues as the grade level 
increases.

Table 11. One-way analysis of variance (ANOVA) results related to the grade variable and attitudes towards environmental issues

\begin{tabular}{|c|c|c|c|c|c|c|}
\hline $\begin{array}{c}\text { Source of } \\
\text { Variance }\end{array}$ & $\begin{array}{c}\text { Sum of } \\
\text { Squares }\end{array}$ & Sd & $\begin{array}{c}\text { Mean of } \\
\text { Squares }\end{array}$ & F & p & $\begin{array}{c}\text { Statistical } \\
\text { Significance }\end{array}$ \\
\cline { 1 - 5 } $\begin{array}{c}\text { Among } \\
\text { Groups }\end{array}$ & 1501.480 & 3 & 500.493 & 5.408 & .001 & \multirow{2}{*}{$1-2$} \\
\cline { 1 - 5 } $\begin{array}{c}\text { Within } \\
\text { Groups }\end{array}$ & 28875.492 & 312 & 92.550 & & & $1-4$ \\
\hline Total & 30376.972 & 315 & & & & \\
\hline
\end{tabular}

As shown in Table 11, the difference between the groups was found to be statistically significant $(p<0,05)$. The Tukey-HSD test was used to determine which groups' mean value difference result in such difference. When the results of this test are examined, it could be seen that there was a statistical significance in favor of sophomores when freshmen and sophomores are compared, and in favor of seniors between freshmen and seniors. Furthermore, when the effect size value of the grade variable is examined, it is seen that it has a moderate value $(\mathrm{\eta} 2=0.05)$ (Cohen, 1988). This situation can be interpreted that as the grade levels of pre-service teachers increase, their attitudes towards environmental issues also increase.

\section{Conclusions and Discussion}

In this study, where the attitudes of the pre-service teachers towards the environmental issues are explained descriptively and in terms of various variables, it is observed that the pre-service teachers have high mean scores $(\bar{X}=76.50)$ about the attitudes of environmental issues. Thus, it can be assumed that the attitudes of the pre-service teachers participating in the research towards the environmental issues are high. When the results of the studies about the attitudes of teachers and pre-service teachers towards the environment and environmental problems are examined, it is seen that the attitudes of the participants in general are high or moderate $[33,16,24,1]$. For example, Pe'er, Goldman and Yavetz (2007) found that high attitude scores emerging at the beginning of their work with 765 freshmen, although the writers hypothesized that participants would have lower attitudes towards environmental attitudes as they were freshmen, they came across with a higher attitude scores than they expected. Researchers have pointed out that this may have been due to the fact that environmental issues have been on the agenda more recently and are taking place more in the media. Similarly, in this study participants' attitudes towards $\mathrm{t}$ environmental issues were high. This result obtained in the research may result from the fact that environmental issues in Turkey are coming to more agenda and that environmental courses may affect the attitudes of pre-service teachers.

In this study, some remarkable results were obtained when the answers obtained from the participants were analyzed item by item, besides revealing high attitude scores. $18 \%$ of the pre-service teachers stated that they agree that "it is hard to learn the concepts about the environment" and $18 \%$ of them said that they are undecided about the same item. In this context, $36 \%$ of pre-service teachers -a considerable part of the total groupseem to have negative and unstable attitudes about learning environmental concepts. This result is parallel to the studies in which the environmental knowledge of pre-service teachers is measured. In a study conducted by Teksöz, Boone, Tüzün and Öztekin (2013) with 2311 pre-service teachers in different undergraduate programs, the participants easily answered the basic concepts of environment (i.e. definition of biodiversity), whereas the participants were challenged by the questions related to the nature of mutual relationships among different environmental knowledge and gave wrong answers. In another study conducted with pre-service elementary teachers, it was emphasized that the participants had limited knowledge about the environmental issues though they were interested in environmental protection and that the enforcement rate of environmental programs in schools was low, which is due to the lack of environmental knowledge of pre-service teachers [41].

It is seen that $77 \%$ of the pre-service teachers did not agree (I disagree: $55 \%$ / I strongly disagree: $22 \%$ ) in the item "I teach the topics about the environment only because they are on the curriculum" on the scale. This situation can be interpreted that pre-service teachers are sensitive to environmental issues even though these topics are not in the program, and they want to dwell on these topics in their courses. Similarly, it is seen that $86 \%$ of the participants did not agree (46\% I disagree / 40\% I strongly disagree) in "I would not teach the topics about the environment if it were an option". This result shows that only $14 \%$ of pre-service teachers are negative $(6 \%)$ or undecided $(8 \%)$ at the point of teaching environmental issues. It can also be said that this situation gives us clues about pre-service teachers' enthusiasm and efforts to teach environmental issues to their future students. Indeed, it is known that teachers' epistemological beliefs and orientations about teaching and learning about a subject strongly influence classroom practices related to that subject [Magnusson, Krajcik, and Borko, 1999, as cited in 9]

On the other hand, although the higher proportion of pre-service teachers who have positive attitudes towards such items involving similar judgments as "I would like to subscribe to a magazine/magazines that are published about environmental issues" (I agree / I strongly agree: 48\%; I am undecided / I disagree: 49\%), "I always want to buy books or magazines about the environment whenever I come across " (I agree / I strongly agree: 49\%; I am undecided / I disagree: 48\%), "I would like to be a member of non-governmental organizations that work for environmental issues" (I agree / I strongly agree: 61\%, I am undecided / disagree: $36 \%$ ), a considerable amount of them 
do not agree with these statements, or they are undecided.

Likewise, a significant proportion of teacher candidates did not participate or were undecided for the items such as "I attend seminars or conferences on environmental issues" (I agree / I strongly agree: 59\%; I am undecided / I disagree: $39 \%$ ), "I follow the environmental issues from visual / written / social media" (I agree / I strongly agree 62; I am undecided / I disagree: 36\%). As emphasized in the literature, one of the most important aims of environmental education in recent years has been to raise environmentally-literate individuals. According to Roth (1992), environmental literacy has four basic dimensions. These dimensions consist of knowledge, skill, sensing and behavior. It is considered remarkable that the negative answers given to these items, which are related to the levels of environmental literacy and the feelings and behavior of the pre-service teachers, who would be a bridge in environmental education, stand out as an attention-taking result.

When the results of the study are examined, it is seen that the pre-service teachers generally have high attitude scores, but as mentioned above, they tend to give negative or undecided responses to the items questioning active participation in environmental issues and measuring behavior. Likewise, in a study with pre-service elementary teachers conducted by Taylor et al. (2007), the writers found that participants, despite their adoption of an "environmental paradigm" to protect the environment, were not willing to change their way of life to do so and did not believe it was necessary. They emphasized the fact that participants did not link the use of resources with waste production or consumption and environmental damage. Likewise, in a study conducted with pre-service science teachers and social science teachers, Sadık (2013) found that, despite the positive environmental considerations of pre-service teachers, environmental behavior attitude scores were not sufficient. The survey revealed that pre-service teachers hardly ever read popular magazines, articles, books, newspaper or news about environmental topics. It was also stated that positive attitudes towards the environment may not be sufficient to develop positive behavior.

When the attitudes of the pre-service teachers to the environmental issues were examined in terms of various variables, it was seen that the attitudes of the participants did not differ significantly according to gender, undergraduate program and the longest duration of residence. However, it has been shown that the attitudes of the pre-service teachers towards the environmental issues are significantly different according to whether they have taken environmental courses, participated in any activities related to the environment, held a membership of any community related to the environment, and grade level.

It is seen that the studies examining some of these variables in the literature mostly focus on environmental knowledge, attitudes towards the environment and environmental problems, environmental responsibility and anxiety $[47,17,12,2,22,27,5]$. Although the characteristics measured in our study are not direct attitudes towards the environment and environmental problems, they are related to the content of these studies in the literature. As a matter of fact, while the results of our study are in parallel with those of some studies, it also differs from some of them.

This study found that the attitude scores of the pre-service teachers did not show any statistical significance according to gender. On the other hand, it has been shown that the attitudes of the teachers and pre-service teachers towards the environment are higher in favor of women in most of the studies conducted related to the attitudes of teachers and pre-service teachers towards the environment based on the gender factor [47, 1, 27]. According to Mohai (1991), women are much more concerned about environmental problems than men and are very interested in this issue [as cited in 40]. As Mohai (1991) emphasizes, researchers who have found results in this direction have made comments that women are more sensitive to the environment and environmental problems than men. Al-Dajeh (2012), who achieved similar results with our study, revealed that the environmental knowledge, attitudes and concerns of the participants did not differ in terms of gender in the study with 124 teacher candidates. Bord and O'Connor (1997) reported that the reason for the different outcomes of gender variables in the research might be due to the measuring tool used in the study. The writers stated that women's scores are higher when the scale includes materials that emphasize a perception of an environmental risk. However, there is no difference between the genders in terms of items including environmental and economic activities, pollution management, and etc. In this study, it can be said that the reason why the attitudes do not differ according to the gender is due to the use of a measurement tool which stands out for measuring the attitudes of the participants to the learning and teaching of the environmental issues rather than a measurement tool which emphasizes the risk perception while the data are collected.

In the study, it was seen that the attitudes of the pre-service elementary teachers and science teachers towards environmental issues did not differ. It has been observed that there are different results in some studies in which attitudes are examined according to the undergraduate program [23, 24]. For example, Kâhyaoğlu and Özgen (2011) found in their study conducted with pre-service teachers in different programs at different universities that pre-service teachers studying at social sciences education and science education programs had a higher level of attitudes towards environmental problems than those of pre-service teachers studying at the elementary education and mathematics education.

The writers indicated that this result might result from the fact that the number of courses on environmental issues 
taken by pre-service teachers studying in the social sciences education and science education programs is more than the number of courses taken by elementary education and mathematics education programs during the four-year study. In our study, the reason why there is no significant difference in terms of education programs may depend on the fact that pre-service science teachers participated in the study have taken a course called "environmental science", and pre-service elementary teachers have taken a course called "environmental education", which both have similar contents. In sum, it can be said that the different results observed in the literature related to the education program variable may be assumed to be related to the study groups' background about environment lessons.

No differentiation has been observed in pre-service teachers' attitudes according to the longest duration of residence. On the other hand, Ek, Kılıç, Öğdüm, Düzgün and Şeker (2009) stated that university students in different programs show a statistical significance in favour of students living in the metropolis area between the students living in the metropolis area and those living in the village in their study on attitudes towards environmental problems and sensitivities. Similarly, Şama (2003) stated that the relationship between the longest duration of residence for university students and their environmental attitudes is statistically significant for those living in metropolis areas. Researchers who achieved similar results viewed the intensity of environmental problems in large settlements as an important factor in the emergence of this disparity. In addition, according to Şama (2003), this is the result of social and cultural change in large cities affecting the attitude toward the environment. As can be clearly seen, the results of this study are different from the results of the studies in the literature. In recent years, environmental problems and environmental issues have gained a more global dimension. People living in rural and urban areas face environmental issues. In addition, environmental issues are now more common in the visual / written / social media. It is thought that these situations solve possible disparities arising from location factors.

When the results obtained by considering the grade levels of the pre-service teachers were examined, it was seen that the attitudes towards the environmental issues differed. The statistical significance among the attitudes of the participants shows that there is a statistical significance in favor of sophomore students when freshman students and sophomore students are compared, whereas there is a statistical significance in favor of senior students when freshman students and senior students are compared. It can be argued that this result may be due to the fact that sophomore and senior students have taken compulsory and elective courses related to environmental education. This result of the research is similar to the results of the studies performed by Çabuk and Karacaoğlu (2003) and Akıllı and Yurtcan (2009) with the pre-service teachers in different programs. According to the researchers, the higher is the university students' grade levels, the higher is their environmental sensitivity. Based on all these similar results, it can be said that pre-service teachers who take elective or mandatory courses related to the environment are ahead of other groups in terms of environment and environmental problems as well as attitudes towards learning and teaching environmental issues. As a matter of fact, the other finding in the study directly supports this result. Pre-service teachers' attitudes towards environmental issues revealed a statistical significance in favor of those who took lessons when compared to those who did not take environmental courses.

In addition, according to whether or not pre-service teachers participate in any activity related to the environment and whether or not they are members of any community, it turns out that attitudes in favor of the participants who participate in the activity and who are members of the community differ. Likewise, Ek, Kılıç, Öğdüm, Düzgün and Şeker (2009) found a statistical significance between the average scores of students who participated in the activities and the scores of Environmental Attitude Scale, although their participation in any activities related to the environment was very limited. The average scores of the Environmental Attitude Scale scores of the students in the activities are higher than those who do not participate in the activities. According to the researchers, students' perceptions of their surroundings and the knowledge they gained with individual activities in various educational stages affect the environmentally related values and attitudes positively. In his work Karatekin (2011) also stated that the teachers who are interested in nature activities in their free time have higher attitudes towards the environment. In this context, it can be said that the behavior that require active participation such as membership to the environmental community, participation in environmental activities, taking care of nature activities and experiencing the environment positively affects attitudes towards both the environment and environmental problems as well as learning and teaching of environmental issues.

In our study, where the attitudes of pre-service teachers towards the environmental issues are explained descriptively and in terms of various variables, the limitation of this study is to determine the participants with convenient sampling method. In this context, quantitative studies similar to this study can be made where more generalized results can be obtained with larger sample groups. However, qualitative studies can be carried out for the purpose of revealing the underlying causes of some remarkable results in the study. As a result; it may be advisable to plan the contents of the courses related to environmental education at the education faculties so that they are based on more active learning, in order to change the existing negative attitudes towards the learning and teaching of environmental subjects. In these courses, environmental publications, printed publications such as 
books, TV programs, social media addresses and environmental communities can be promoted. In addition, pre-service teacher candidates can be encouraged to develop projects related to environmental activities and a number of activities can be organized for the implementation of these projects. According to Scott (1996), the causes of problems in the preparation of teachers for environmental education include the lack of a shared pedagogical approach to pre-service teachers for environmental education and the lack of use of active learning strategies by focusing on the transfer of knowledge in the education of environmental issues. Thus, it can be guided to educational programs with practical work (action research, etc.) to improve the environmental attitudes of teachers and pre-service teachers.

\section{REFERENCES}

[1] Ahi, B., \& Özsoy, S. (2015). Elementary school teachers' attitudes towards environment: gender and Professional seniorty factors. Kastamonu Education Journal, 23(1), 31-56.

[2] Akıllı, M., \& Yurtcan, M. T. (2009). İlköğretim Fen Bilgisi Öğretmeni Adaylarının Çevreye Karşı Tutumlarının Farklı Değişkenler Açısından İncelenmesi (Kazım Karabekir Eğitim Fakültesi Örneği). Erzincan Eğitim Fakültesi Dergisi, $11,119-131$.

[3] Aldrich, M., \& Benjamin, C. (1997). Environmental Education. London: The IEA Education and Training Unit and the IEA Environment Unit.

[4] Ashmann, S., \& Franzen, R. L. (2017). In what ways are teacher candidates being prepared to teach about the environment? A case study from Wisconsin. Environmental Education Research, 23(3), 299-323.

[5] Al-Dajeh, H. (2012). Assessing Environmental Literacy of Pre-Vocational Education Teachers in Jordan. College Student Journal, 46(3), 492-507.

[6] Bord, R. J. \& O'Connor, R. E. (1997). The gender gap in environmental attitudes: The case of perceived vulnerability to risk. Social Science Quarterly, 78(4), 830-840.

[7] Casas, A. B., \& Burgess, R. A. (2012). The practical importance of philosophical inquiry for environmental professionals: A look at the intrinsic/instrumental value debate. Environmental Practice: Journal of the National Association of Environmental Professionals, 14(3), 184-189.

[8] Cheng, J. C. H., \& Monroe, M. C. (2010). Examining teachers' attitudes toward a required environmental education program. Applied Environmental Education \& Communication, 9(1), 28-37.

[9] Cheng, I. N. Y. \& So, W.W.M. (2015). Teachers' environmental literacy and teaching stories of three Hong Kong primary school teachers. International Research in Geographical and Environmental Education, 24(1), 58-79.
[10] Cocks, S., \& Simpson, S. (2015). Anthropocentric and ecocentric: An application of environmental philosophy to outdoor recreation and environmental education. Journal of Experiential Education, 38(3) 216-227

[11] Cohen, J. (1988). Statistical power analysis for the behavioral sciences (2nd Ed.). Hillsdale, NJ: Erlbaum.

[12] Çabuk, B. \& Karacaoğlu, C. (2003). Üniversite ögrencilerinin çevre duyarlılıklarının incelenmesi. Ankara Üniversitesi Eğitim Bilimleri Fakültesi Dergisi, 36(1-2), 189-198.

[13] Çepel, N. (2010). Ekoloji, doğal yaşam dünyalarl ve insan (1th Ed.). Ankara: Palme Yayınevi.

[14] De Lavega, E. L. (2004). Awareness, knowledge, and attitude about environmental education: Responses from environmental specialists, high school instructors, students, and parents. Education in Curriculum and Instruction in the College of Education at the University of Central Florida. Orlando, Florida.

[15] Donnelly, B., \& Bishop, P. (2007). Natural law and ecocentrism. Journal of Environmental Law, 19(1), 89-101.

[16] Esa, N. (2010). Environmental knowledge, attitude and practices of student teachers. International Research in Geographical and Environmental Education, 19(1), 39-50.

[17] Ek, H. N., Kılıç, N., Öğdüm, P., Düzgün, G., \& Şeker, S. (2009). Adnan Menderes Üniversitesinin farklı akademik alanlarında öğrenim gören ilk ve son sınıf öğrencilerinin çevre sorunlarına yönelik tutumları ve duyarlılıkları. Kastamonu Eğitim Dergisi, 17(1), 125-136.

[18] Fraenkel, J. R., Wallen, N. E., \& Hyun. H. H. (2012). How to design and evaluate research in education (8th Edition). The McGraw-Hill Companies, New York.

[19] Gayford, C.G., \& Dillon, P.J. (1995). Policy and the practice of environmental education in England: A dilemma for teachers. Environmental Education Research, 1(2), 173-184.

[20] Gifford, R., \& Sussman, R. (2012). "Environmental Attitudes." In The Oxford Handbook of Environmental and Conservation Psychology, edited by S. Clayton, 65-80. New York: Oxford University Press.

[21] Harden, R.M., \& Crosby, J.R. (2000). AMEE education guide no. 20: The good teacher is more than a lecturer the twelve roles of the teacher. Medical Teacher, 22(4), 334-347.

[22] Karatekin, K. (2011). Sosyal Bilgiler Öğretmen Adaylarının Çevre Okuryazarlık Düzeylerinin Belirlenmesi, Unpublished doctoral dissertation, Gazi Üniversitesi Eğitim Bilimleri Enstitüsü, Ankara.

[23] Kahyaoğlu, M., Daban, Ş., \& Yangın, S. İlköğretim ögretmen adaylarının çevreye yönelik tutumları. Dicle Üniversitesi Ziya Gökalp Eğitim Fakültesi Dergisi, 11, 42-52.

[24] Kahyaoğlu, M., \& Özgen, N. (2012). An investigation of pre-service teachers' attitudes towards environmental problems in terms of several variables. Journal of Theoretical Educational Science, 5(2), 171-185.

[25] Kibert, C. N. (2000). An analysis of the correlations between the attitude, behavior, and knowledge components of 
environmental literacy in undergraduate university students. Unpublished Master Dissertation, The Graduate School of the University Of Florida, USA.

[26] Lahiri, S. (2011). Assessing the environmental attitude among pupil teachers in relation to responsible environmental behavior: A leap towards sustainable development. Journal of Social Sciences, 7(1), 33-41.

[27] Larijani, M. (2010). Assessment of environmental awareness among higher primary school teachers. Journal of Human Ecology, 31(2), 121-124.

[28] Liefländer, A. K., \& Bogner, F. X. (2016). Educational impact on the relationship of environmental knowledge and attitudes Environmental Education Research.

[29] Mosseley, C. (2000). Teaching for Environmental Literacy. Clearing House. 74(1), 23-25.

[30] O’Brien, M. R. S. (2007). Indications of environmental literacy: using a new survey instrument to measure awareness, knowledge, and attitudes of university-aged students. Unpublished master dissertation, Iowa State University, USA.

[31] Odum, E. P., \& Barrett, G. W. (2008). Ekolojinin Temel Ilkeleri (1th Edition). Ankara: Palme Yayınevi.

[32] Özoğlu, S. (1993). Yaygın eğitim düzeyinde çevre için eğitim çevre eğitimi. Ankara: Türkiye Çevre VakfıYayını.

[33] Pe'er, S., Goldman, D. \& Yavetz B. (2007). Environmental literacy in teacher training: attitudes, knowledge, and environmental behavior of beginning students. The Journal of Environmental Education, 39(1), 45-59.

[34] Polat, Ö.D. (1999). Türkiye' de çevre eğitminin durumu. Unpublished master dissertation, Akdeniz Üniversitesi, Antalya.

[35] Reece, J. B., Urry, L. A., Cain, M. L., Wasserman, S. A., Minorsky, P. V., Jackson, R. B. Et.al. (2013). Campbell Biyoloji (9th Edition). Ankara: Palme Yayınc1lik.

[36] Roth, C.E. (1992). Environmental literacy: its roots, evolution and directions in the 1990s. http://www.eric.ed.gov/ERICDocs/data/ericdocs2sq1/conten t_storage_01/0000019b/80/24/44/47.pdf.

[37] Sadik, F. (2013). Investigating environmental attitudes and knowledge levels of teacher candidates in terms of different variables. Pegem Journal of Education \& Instruction, 3(4), 69-82.

[38] Saraç, E., \& Kan, A. (2015). Öğretmen adayları için çevre konularına yönelik tutum ölçeği geliştirme geçerlik ve güvenirlik çalışması. Journal of Research in Education and Teaching, 4(2) 142-150.

[39] Schultz, P. W., Shriver, C., Tabanico, J. J., \& Khazian, A.M. 2004. "Implicit Connections with Nature." Journal of Environmental Psychology $24 \quad$ (1): 31-42. doi:http://dx.doi.org/10.1016/S0272-4944(03)00022-7.

[40] Spellman, G., Field, K., Sinclair, J. (2003). An investigation into UK higher education students' knowledge of global climatic change. International Research in Geographical and Environmental Education, 12(1), 6-17.

[41] Spiropoulou, D., Antonakaki, T., Kontaxakaki, S., \& Bouras, S. (2007). Primary teachers' literacy and attitudes on education for sustainable development. Journal of Science Education and Technology, 16, 443-450.

[42] Şama, E. (2003). Öğretmen adaylarının çevre sorunlarına yönelik tutumları. Gazi Üniversitesi Gazi Eğitim Fakültesi Dergisi, 23(2), 99-110.

[43] Scott, W. (1996). The Environmentally Educating Teacher: Synthesis of an Implementation Theory for Pre-service Courses. Australian Journal of Environmental Education, $12,53-60$

[44] Summers, K. C., \& Childs, A. (2000) Teaching sustainable development in primary schools: An empirical study. Environmental Education Research, 6(4), 293-312.

[45] Szerényi, Z.M., Zsóka, Á., \& Széchy, A., (2009). Environmental education and pro-environmental consumer behaviour-results of a university survey. Joint Actions on Climate Change, Denmark. file:///C:/Users/Samsung/Downloads/Zsoka_Szechy_Szeren yi.pdf

[46] Taylor, N., Doff, T., Jenkins, K., \& Kennelly, J. (2007). Environmental Knowledge and Attitudes among a Cohort of Pre-service Primary School Teachers in Fiji. International Research in Geographical and Environmental Education, 16(4), 367-379.

[47] Teksöz, G. T., Boone, J.W., Tüzün, O. Y., \& Öztekin, C. (2014). An evaluation of the environmental literacy of preservice teachers in Turkey through Rasch analysis. Environmental Education Research, 20 (2), 202-227.

[48] Vlaardingerbroek, V., \& Neil Taylor, T. G. (2007). The Environmental Knowledge and Attitudes of Prospective Teachers in Lebanon: A comparative study. International Research in Geographical and Environmental Education, 16(2), 120-134. 